\title{
EKSPLORASI ETNOMATEMATIKA PADA PEMBUATAN KUBAH MASJID BERBAHAN STAINLESS STEEL SEBAGAI BAHAN LEMBAR KERJA SISWA
}

\author{
Nurul Annisa ${ }^{1}$, Titik Sugiarti ${ }^{2}$, Lioni Anka Monalisa ${ }^{2}$, Sunardi $^{2}$, Dinawati \\ Trapsilasiwi ${ }^{2}$ \\ Program Studi Pendidikan Matematika, FKIP, Universitas Jember \\ Jalan Kalimantan 37 Kampus Tegalboto Jember 68121 \\ E-mail: nurulannisa.fkip@gmail.com
}

\begin{abstract}
Ethnomatics are cultural practices related to mathematical activities such as grouping, counting, calculating, designing buildings or tools, determining locations. This research was conducted at the Soponyono Dome Company, Wirolegi, Jember. The purpose of this study is to describe ethnomatematics in the manufacture of stainless steel mosque domes and produce student worksheets. This research is a type of qualitative research with ethnographic approach. Data collection methods used are observation, interviews and documentation. The subjects of this research are the owner of the company and four dome craftsmen. Geometry concepts or elements found include: congruent, flat shapes (rectangle, irregular hexagon, circle segment, trapezoid), space structures (cylinder, truncated ball, cone, and truncated cone), geometrical transformations (dilatation), and mathematical activity (measuring activity, counting activity, and design activity). The results of the study were made as worksheet material for Grade VII students with the subject of constructing curved side spaces of tube and cone material.
\end{abstract}

Keywords: Ethnomatematics, Mosque Dome, Student's Worksheet..

\section{PENDAHULUAN}

Perkembangan Ilmu Pengetahuan dan Teknologi (IPTEK) memberikan kontribusi yang cukup besar terhadap kemajuan pendidikan. Perkembangan teknologi pendidikan yang sedang gencar ini, tidak membuat kurikulum pendidikan di Indonesia mengesampingkan keterlibatan budaya dalam pembelajaran dengan tujuan agar siswa menjadi generasi bangsa yang memiliki karakter. Hakikatnya pendidikan adalah seperangkat sarana untuk membudayakan nilai-nilai budaya masyarakat yang mungkin dapat mengalami perubahan bentuk dan model sesuai tuntutan kebutuhan hidup masyarakat dalam rangka mengejar cita-cita hidup sejahtera lahir dan batin [1]. Kaitan budaya dengan pendidikan ini berlaku secara umum tidak terkecuali perkembangan ilmu pengetahuan di bidang matematika.

\footnotetext{
${ }^{1}$ Mahasiswa S1 Prodi Pendidikan Matematika FKIP Universitas Jember

${ }^{2}$ Dosen Prodi Pendidikan Matematika FKIP Universitas Jember
} 
Salah satu ranah kajian yang mengaitkan matematika dan budaya adalah etnomatematika. Konsep matematika dapat digali dalam budaya, khususnya budaya dapat dimanfaatkan sebagai salah satu sumber belajar matematika yang nyata bagi siswa. Etnomatematika juga menyediakan lingkungan belajar yang membangun motivasi siswa sehingga pembelajaran matematika menyenangkan. Salah satu objek etnomatematika adalah masjid. Masjid adalah tempat ibadah umat Islam dan merupakan suatu karya seni dan budaya di bidang arsitektur. Ciri khusus dari sebuah masjid adalah bentuk kubah yang futuristik. Dalam penggunaannya, kubah masjid ada yang digunakan sebagai struktur dan kontruksi, namun ada juga yang digunakan sebagai ornamen estetika. Penggunaan kubah pada awalnya digunakan sebagai pembeda posisi mihrab dengan jamaah shalat. Kubah diposisikan tepat di atas tempat imam shalat [2]. Bentuk kubah masjid di Indonesia banyak yang mengadopsi bentuk sebuah bola yang terpotong. Berdasarkan material yang digunakan juga bermacam-macam antara lain material lembaran stainless steel, lembaran besi, beton cor, lembaran galvanum, dan sebagainya.

Stainless steel merupakan baja paduan yang memiliki sifat ketahanan korosi (karat) sehingga secara luas digunakan dalam industri kimia, makanan, dan minuman, industri yang berhubungan dengan air laut dan semua industri yang memerlukan ketahanan korosi [3]. Berdasarkan keunggulan tersebut, banyak pemanfaatan material stainless steel dalam sektor industri, salah satunya industri kubah masjid yang ada di Desa Wirolegi, Kecamatan Sumbersari, Kabupaten Jember.

Bagian penting dalam kegiatan pembelajaran adalah pemilihan bahan ajar yang digunakan, bahan ajar yang tepat membantu siswa mencapai kompetensi yang akan digunakan. Salah satu bahan ajar tertulis yaitu Lembar Kerja Siswa (LKS). LKS berisi serangkaian kegiatan dasar yang harus dilakukan oleh siswa dengan tujuan memaksimalkan pemahaman dan kemampuan dasar pembentukan siswa dalam penacapaian hasil pembelajaran yang diharapkan [4]. Rumusan masalah dalam penelitian ini adalah bagaimanakah etnomatematika pada 
pembuatan kubah masjid berbahan stainless steel sebagai bahan lembar kerja siswa.

\section{METODE PENELITIAN}

Penelitian ini menggunakan penelitian kualitatif dengan pendekatan etnografi. Penelitian kualitatif merupakan penelitian yang bertujuan untuk mendeskripsikan fenomena, peristiwa, aktivitas social, sikap, kepercayaan, persepsi, pemikiran orang baik individu maupun kelompok [5]. Etnografi merupakan desrkripsi yang mengacu pada hasil manuskrip tentang kebudayaan suatu komunitas/masyarakat [6].

Pengambilan data dilakukan pada tanggal 26 November - 9 Desember 2019 di perusahaan kubah Soponyono Wirolegi Jember. Subjek penelitian ada 5 orang, yaitu pemilik perusahaan kubah Soponyono dan empat pengrajin kubah masjid. Metode pengumpulan data dalam penelitian ini yaitu observasi, wawancara, dan dokumentasi. Penelitian ini menggunakan observasi partisipan dan wawancara semi terstruktur. Pada metode dokumentasi, dilakukan pengambilan foto bentuk dan jarring-jaring kubah masjid berbahan stainless steel, serta perekaman suara saat wawancara. Prosedur penelitian yang dilakukan untuk mencapai tujuan dalam penelitian ini dapat dilihat pada Gambar 1 sebagai berikut.

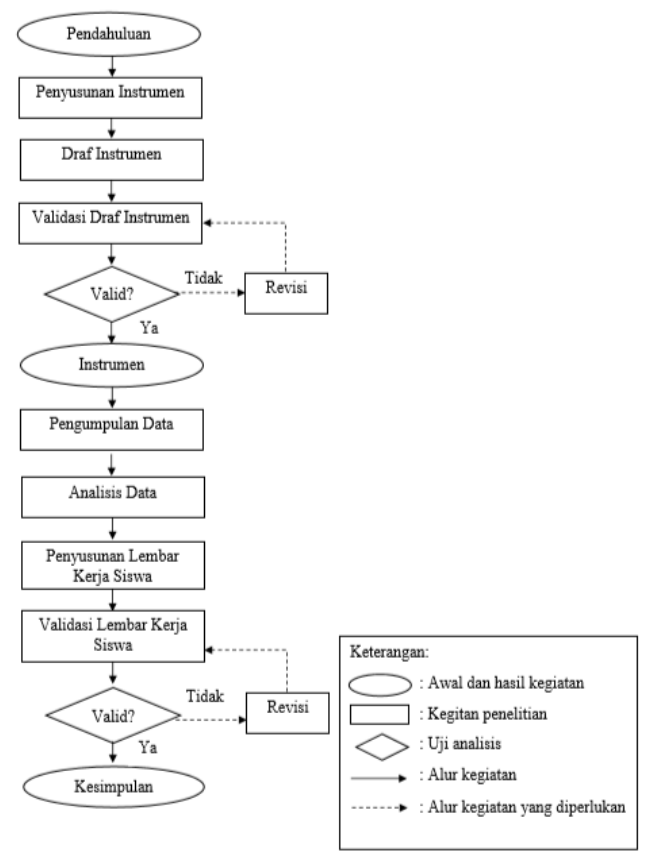

Gambar 1. Prosedur Penelitian 


\section{HASIL DAN PEMBAHASAN}

Perusahaan kubah Soponyono yang terletak di desa Wirolegi, kecamatan Sumbersari, kabupaten Jember adalah salah satu rumah industri kubah masjid berbahan stainless steel yang memiliki konsep-konsep matematika dalam bentuk maupun proses pembuatannya. Adapun konsep matematika yang ada pada pembuatan kubah masjid yaitu kekongruenan, bangun datar, bangun ruang, dan transformasi geometri. Kaki kubah memiliki kesamaan bentuk dengan leher kubah dan variasi lafal namun ukruan ketiganya berbeda, selain itu terdapat konsep tabung dan konsep persegi panjang pada jaring-jaringnya.

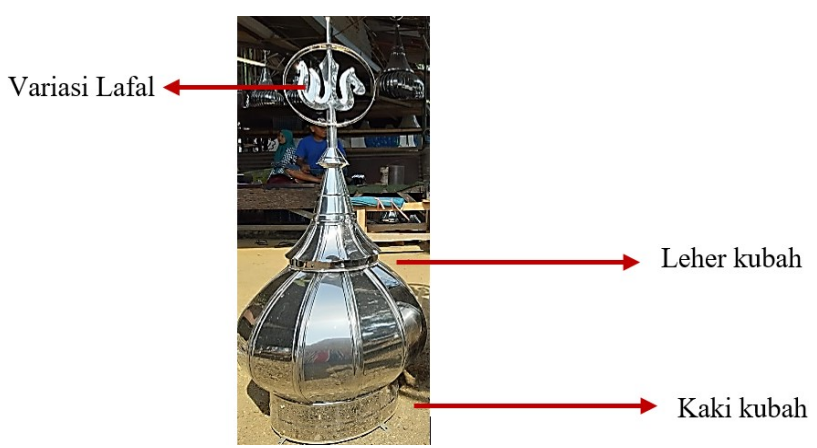

Gambar 2. Illustrasi dilatasi pada kaki, leher, dan variasi lafal kubah

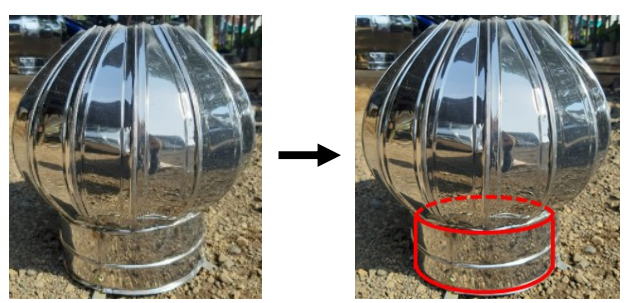

Gambar 3. Ilustrasi Tabung pada Bentuk Kaki Kubah

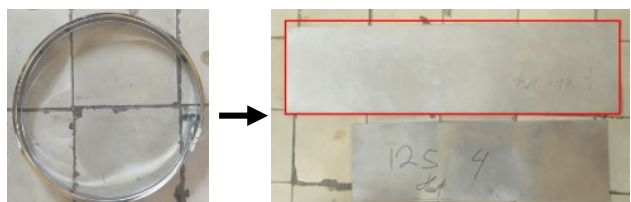

Gambar 4. Ilustrasi Jaring-jaring Kaki Kubah Masjid

Perut kubah adalah bagian terpenting pada proses pembuatan kubah masjid berbahan stainless steel karena bagian ini adalah bagian awal yang dikerjakan dalam pembuatan kubah masjid. Perut kubah masjid memiliki bentuk bola terpotong, konsep segienam pada jaring-jaring, dan konsep kekongruenan karena setiap lapisan yang menyusun perut kubah memiliki bentuk yang simetris. 


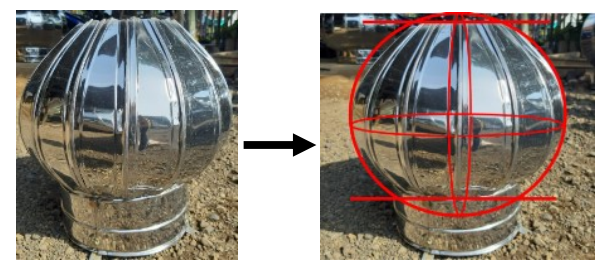

Gambar 5. Ilustrasi Bola Terpotong pada Perut Kubah Masjid

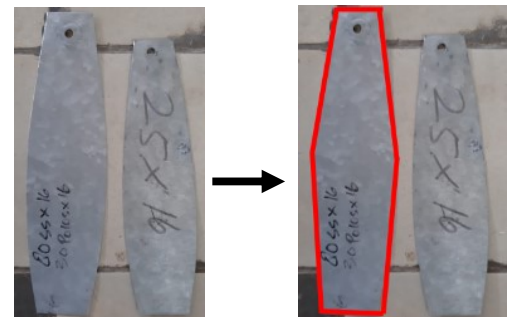

Gambar 6. Ilustrasi Kekongruenan Lapisan Perut Kubah

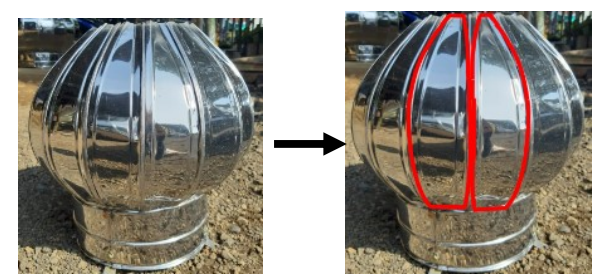

Gambar 7. Ilustrasi Kekongruenan Lapisan Perut Kubah

Pembuatan perut kubah berdiameter tengah $40 \mathrm{~cm}$ dibentuk dari $12 \mathrm{mal}$ dengan panjang tengah mal $11 \mathrm{~cm}$, panjang atas $7 \mathrm{~cm}$, dan panjang alas 9,5 cm. Ukuran-ukuran tersebut ditetapkan setelah melakukan beberapa percobaan. Menurut konsep matematika, ukuran-ukuran tersebut dapat ditentukan dari hasil perhitungan keliling lingkar tengah perut kubah dibagi dengan banyaknya lapisan yang menyusun perut kubah. Secara matematis dapat ditulis $K=\pi d=\frac{22}{7} \times 40=125,71 \mathrm{~cm}$, keliling lingkar tengah kemudian dibagi dengan banyaknya lapisan (mal) dalam satu perut kubah sehingga panjang tengah mal adalah $\frac{125,71}{12}=10,48 \mathrm{~cm}$. Ada selisih perhitungan antara pengrajin dan konsep matematika tidak lebih dari $1 \mathrm{~cm}$, hal ini dikarenakan terdapat lipatan di sisi kanan dan kiri mal yang digunakan sebagai pengait.

Keliling lingkar tengah perut menjadi pijakan untuk memperoleh ukuran bagian kubah yang lain. Jika panjang tengah mal perut $11 \mathrm{~cm}$ maka lingkar tengah perut kubah yaitu $11 \times 12=132 \mathrm{~cm}$. Ukuran lingkar atas perut kubah 
mengindikasikan ukuran leher kubah. Panjang sisi atas mal $7 \mathrm{~cm}$, sehingga diperoleh lingkar atas perut kubah $7 \times 12=84 \mathrm{~cm}$. Ukuran lingkar bawah perut kubah dapat mengindikasikan ukuran lingkar kaki kubah. Panjang sisi bawah mal 9,5 cm, sehingga diperoleh lingkar atas perut kubah 9,5×12=114 cm. Berdasarkan hasil perhitungan tersebut, lingkar bawah : lingkar tengah : lingkar atas $=1,3: 1,5: 1$. Menggunakan cara yang sama untuk ukuran lingkar perut kubah berdiameter $50 \mathrm{~cm}$ dengan panjang bawah, tengah, dan atas mal berturutturut $11 \mathrm{~cm}, 14 \mathrm{~cm}$, dan $7 \mathrm{~cm}$ diperoleh perbandingan $1,5: 2: 1$.

Terdapat konsep perkalian, pembagian dan penjumlahan dalam proses penjiplakan mal perut kubah. Berdasarkan hasil observasi, pengrajin melakukan penjiplakan secara horizontal menghasilkan 61 pola, sedangkan secara vertical dengan perhitungan matematika menghasilkan 63 pola.

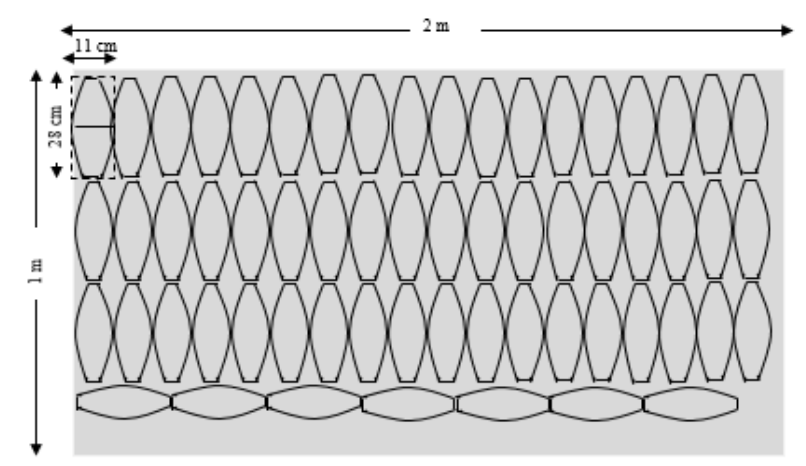

Gambar 8. Ilustrasi Penjiplakan Mal Perut Kubah Diameter $40 \mathrm{~cm}$ (Horizontal)

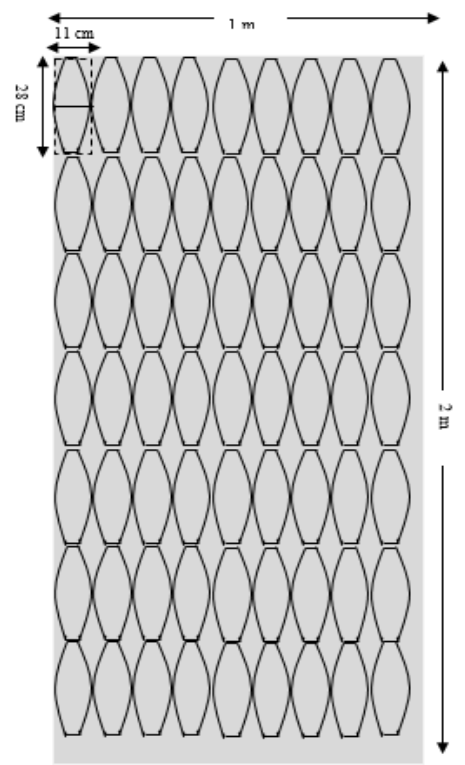

Gambar 9. Ilustrasi Penjiplakan Mal Perut Kubah Diameter $40 \mathrm{~cm}$ (Vertikal) 
Tangkup kubah merupakan bagian makara yang fungsinya menambah nilai estetika kubah. Tangkup kubah memiliki konsep matematika berbentuk gabungang bangun trapesium dan tembereng lingkaran serta kekongruenan.

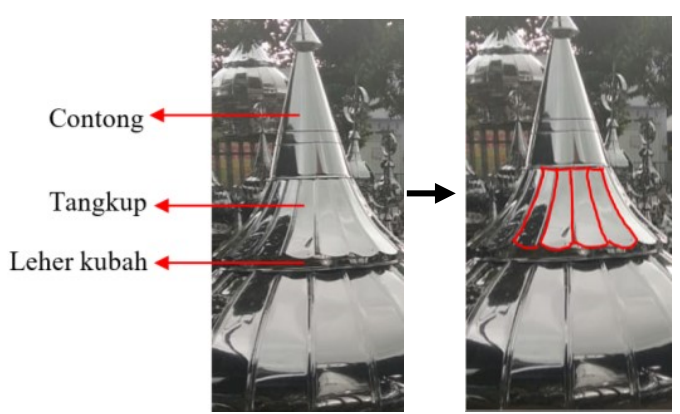

Gambar 10. Ilustrasi Kekongruenan pada Tangkup

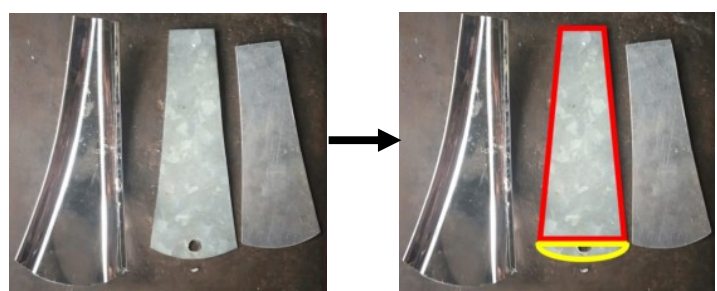

Gambar 11. Ilustrasi Trapesium dan Tembereng Lingkaran pada Tangkup

Contong merupakan bagian makara yang selalu digunakan pada semua model kubah masjid berbahan stainless steel di perusahaan kubah Soponyono. Terdapat konsep bangun ruang kerucut pada contong dan konsep lingkaran pada jaring-jaringnya

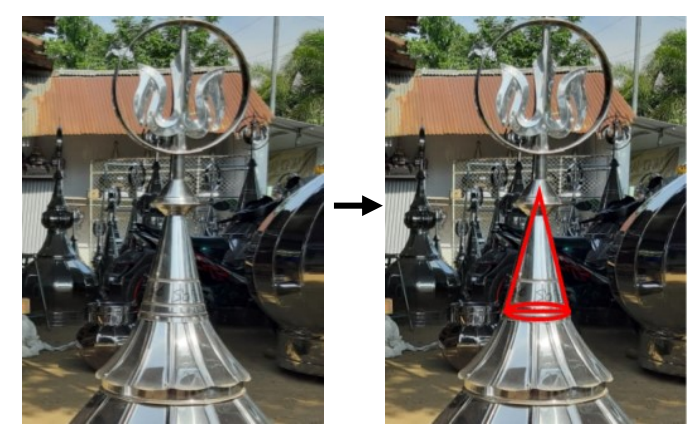

Gambar 12. Ilustrasi Bentuk Kerucut pada Contong Kubah

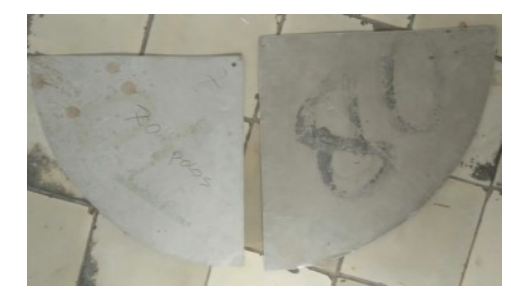

Gambar 13. Mal Contong Kubah 


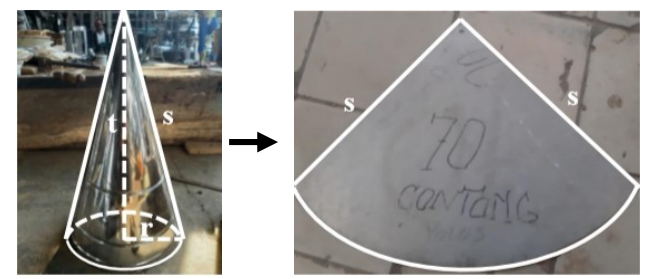

Gambar 14. Ilustrasi Unsur-unsur Kerucut

Variasi makara terletak di atas contong kubah yang sengaja dibuat untuk menambah keindahan kubah. Variasi makara dibagi menjadi dua bagian. yaitu bagian atas dan bagian bawah. Variasi makara memiliki konsep bangun kerucut terpancung dan konsep lingkaran pada jaring-jaringnya. Pembuatan variasi melalui empat percobaan dengan memanfaatkan alas timba. Lubang yang terdapat di tengah mal variasi sengaja dibuat agar puncak contong dapat merekat dengan variasi.

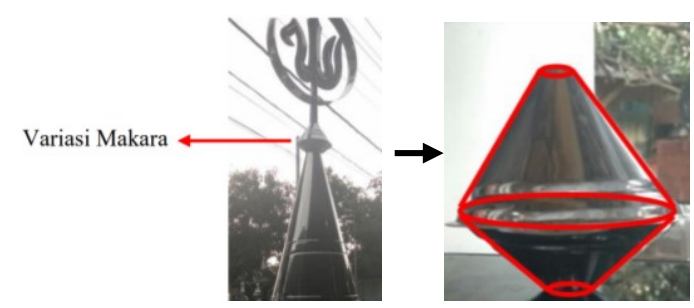

Gambar 15. Ilustrasi Kerucut Terpancung pada Variasi Kubah

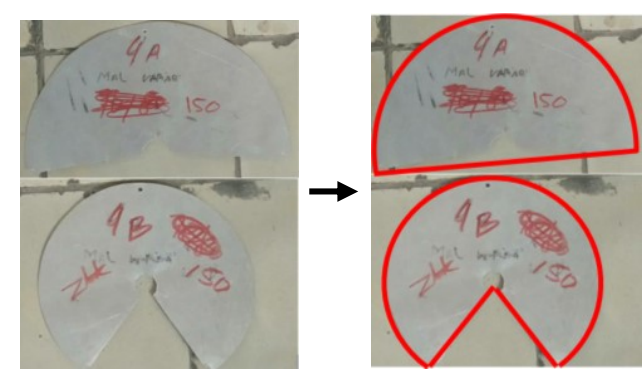

Gambar 16. Ilustrasi Konsep Lingkaran pada Mal Variasi Makara

Tombak kubah merupakan bagian puncak dari kubah masjid. Awalnya bentuk tombak seperti pipa, namun pengrajin terus melakukan inovasi hingga diperoleh bentuk kerucut. Selain itu, mal tombak memiliki konsep trapesium. 


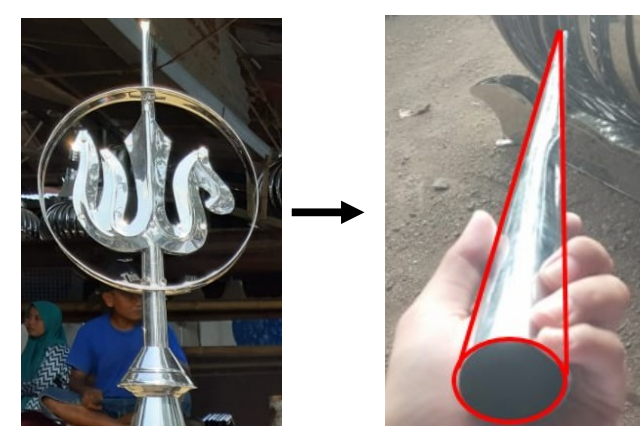

Gambar 17. Ilustrasi Kerucut pada Tombak Kubah

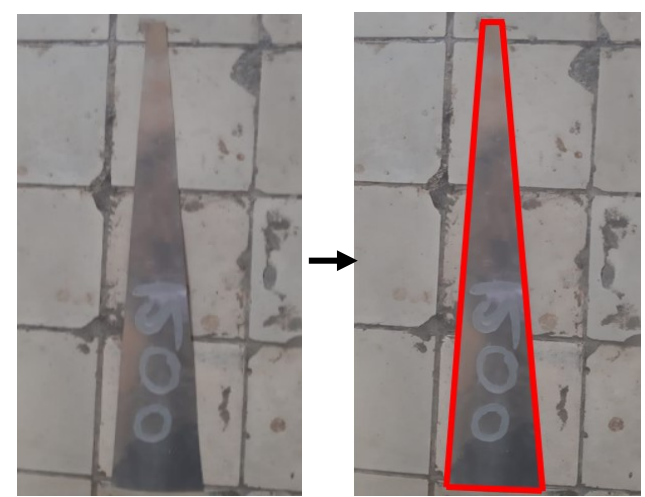

Gambar 18. Ilustrasi Trapseium pada Mal Tombak Kubah

Ukuran emas (golden size) kubah masjid berbahan stainless steel menjadi temuan menarik saat pengrajin membuat desain kubah. Golden size juga sering dikenal dengan divine proportion, golden section golden cut, golden ratio, atau golden mean. Golden ratio dianggap sebagai perbandingan yang menghasilkan bentuk geometris yang indah dan menarik [7]. Golden ratio $(\varphi)$ merupakan hasil dari membagi segmen menjadi dua segmen $(A+B)$, sehingga secara matematis dapat dituliskan sebagai berikut.

$$
\frac{A}{B}=\frac{(A+B)}{A} \approx 1,6180339887, \text { dengan } A>B[8] .
$$

Pengrajin mengatakan kubah yang paling diminati karena bentuknya yang cantik dan indah yaitu kubah bawang ukuran sedang. Kubah memiliki bentuk seperti bawang, lebih bulat dan pendek. 


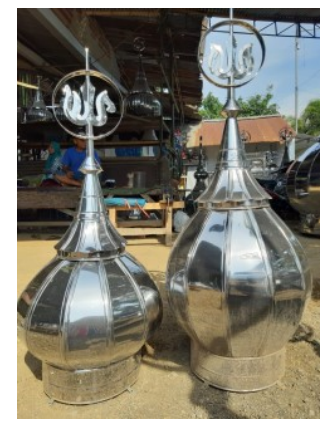

Gambar 19. Kubah bawang (kiri) dan kubah peluru (kanan)

Secara visual, Golden Ratio kubah polos stainless steel terlihat pada Gambar 20. Pembagian yang dapat ditemukan adalah sebagai berikut.

- $\frac{\text { diameter perut kubah }}{\text { tinggi kaki kubah } \mathrm{s} / \mathrm{d} \text { perut kubah }}=\frac{75}{47}=1,6$

- $\frac{\text { tinggi makara kubah }}{\text { tinggi kaki } \mathrm{s} / \mathrm{d} \text { perut kubah }}=\frac{75}{47}=1,6$

- $\frac{\text { tinggi kubah }}{\text { tinggi makara kubah }}=\frac{122}{75}=1,62$

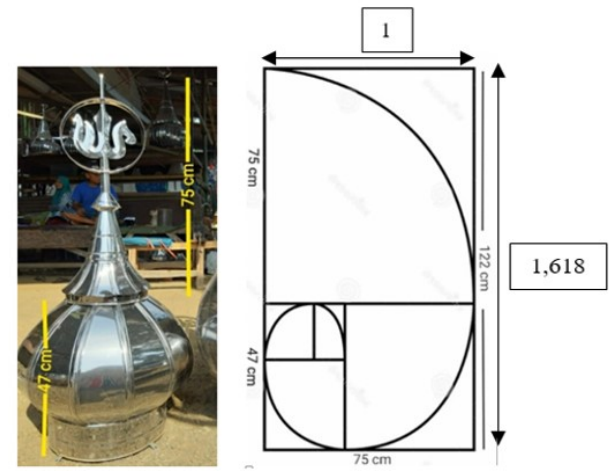

Gambar 20. Golden Ratio dan Spiral Emas pada Kubah

Berdasarkan konsep Golden Ratio, dapat disimpulkan bahwa kubah bawang ukuran sedang tepatnya dengan diameter $75 \mathrm{~cm}$ termasuk kubah yang cantik karena proporsi yang digunakan ideal dan memiliki nilai estetika, hal ini sesuai dengan pendapat pengrajin.

Hasil penelitian ini digunakan bahan LKS untuk SMP/MTs/sederajat kelas IX dengan pendekatan saintifik 5M. LKS menjadi stimulus atau bimbingan guru dalam pembelajran yang akan disajikan secara tertulis sehingga dalam 
penulisannya perlu memperhatikan kriteria media grafis sebagai media visual untuk menarik perhatian siswa [9]. Kevalidan LKS ada 3 kriteria yaitu berdasarkan syarat didaktik, syarat konstruksi, dan sayarat teknis [10].

LKS berisi materi luas permukaan tabung dan kerucut. Pada LKS terdapat kompetensi inti, kompetensi dasar, indikator pencapaian, petunjuk pengerjaan, aspek yang dinilai, dan permasalahan yang berkaitan dengan etnomatematika pada pembuatan kubah masjid berbahan stainless steel yaitu aktivitas menghitung panjang dan lebar kaki kubah, leher kubah, dan lingkaran lafal, menentukan ukuran-ukuran pola kubah, dan menentukan banyaknya bahan yang dibutuhkan untuk membuat kaki kubah dan makara kubah. Lembar kerja siswa dapat dilihat pada link berikut.

https://drive.google.com/file/d/1yZjjNCUbb0iWPVg6AfHw_YLuyYeVlBgN/vie $\underline{\mathrm{w}} \mathrm{usp}=\mathrm{drivesd \textrm {k }}$.

\section{KESIMPULAN}

Berdasarkan hasil dan pembahasan pada penelitian ini, dapat disimpulkan bahwa terdapat etnomatematika pada pembuatan kubah masjid berbahan stainless steel di Wirolegi Jember antara lain kekongruenan, bangun datar (persegi panjang, segienam tak beraturan, trapesium, dan lingkaran), bangun ruang (tabung, bola terpotong, kerucut, dan kerucut terpancung), transformasi geometri (dilatasi), dan pada pembuatan kubah terdapat aktivitas matematika (menghitung, mengukur, dan mendesain). Penelitian ini menghasilkan bahan ajar geometri berupa lembar kerja siswa dengan pokok bahasan bangun ruang sisi lengkung materi luas permukaan tabung dan kerucut.

\section{DAFTAR PUSTAKA}

[1] A. A. Zafi, "Transformasi Budaya melalui Lembaga Pendidikan (Pembudayaan dalam Pembentukan Karakter)," Jurnal LP3M, vol. 3, no. 2, pp. 105-112, 2017.

[2] S. H. Retnoasih dan S. W. Firmandhani, "Makna Kubah Masjid di Pulau Jawa," Jurnal Aristektur, vol. 1, no. 2, pp. 41-44, 2017.

[3] R. Roharjo, "Tingkat Kekerasan Permukaan Stainless Steel 316L Akibat Tekanan Steelballpeening, Proceeding Seminar Nasional Tahunan Teknik Mesin XIV(SNTTMXIV), Universitas Brawijaya, 2015. 
[4] I. Y. Yanti, I. K. Pudjawan, dan I. I. W. Suwatra, "Pengembangan Lembar Kerja Siswa Model Hannafin And Peck untuk Meningkatkan Hasil Belajar," Journal of Education Technology, vol. 4, no.1, pp. 67-72, 2020.

[5] B. S. Bachri, "Meyakinkan Validitas Data Melalui Triangulasi Pada Penelitian Kualitatif," Jurnal Teknologi Pendidikan, vol. 10, no. 1, pp 4662, 2010.

[6] I. D. G. P. Yasa, "Pendekatan Etnografi dalam Karya Foto Dokumenter," Prosiding Seminar Nasional Desain dan Arsitektur (SENADA), Sekolah Tinggi Desain Bali, 2020.

[7] B. F. R. U. Ina, R. A. Panuntun, dan W. Atmojo, "Matematika pada Gapura Bali," Prosiding Seminar Nasional Matematika dan Pendidikan Matematika, Universitas Sanata Dharma, 2018.

[8] Md. Akhtaruzzamamn and A.A. Shafie, "Geometrical Substantiation of Phi, the Golden Ratio and the Baroque of Nature, Architecture, Design and Engineering," Internationat Journal of Arts, vol. 1, no. 1, pp. 1-22 2011.

[9] Y. Astuti dan B. Setiawan, "Pengembangan Lembar Kerja Siswa (LKS) Berbasis Pendekatan Inkuiri Terbimbing dalam Pembelajaran Kooperatif pada Materi Kalor," Jurnal Pendidikan IPA Indonesia, vol. 2, no. 1, pp. 8892, 2013.

[10] L. Watika dan Suliyanah, "Validitas Lembar Kerja Peserta Didik (LKPD) Berbasis Collaborative Learning pada Materi Gerak Lurus di SMA Negeri 1 Driyorejo," Inovasi Pendidikan Fisika, vol. 08, no. 02, pp. 579-582 2019. 